\title{
Optimization of Chromium (Vi) Removal by Donnan Dialysis
}

\author{
I. Marzouk ${ }^{1,2}$, L. Dammak ${ }^{2}$, L. Chaabane ${ }^{2}$, B. Hamrouni ${ }^{1}$ \\ ${ }^{1}$ UR Traitement et Dessalement des Eaux, Faculté des Sciences de Tunis, Université de Tunis El Manar, Manar II, Tunisie \\ ${ }^{2}$ Institut de Chimie et des Matériaux Paris-Est, Université Paris-Est Créteil, Henri Dunant, Thiais, France \\ Email: bhamrouni@gmail.com
}

Received April 7, 2013; revised May 8, 2013; accepted June 1, 2013

Copyright (C) 2013 I. Marzouk et al. This is an open access article distributed under the Creative Commons Attribution License, which permits unrestricted use, distribution, and reproduction in any medium, provided the original work is properly cited.

\begin{abstract}
The removal of chromium (VI) from aqueous solutions by Donnan dialysis has been investigated in this paper. In this process, two anion-exchange membranes (AEMs) were used: Selemion ${ }^{\circledR}$ AMV and Neosepta ${ }^{\circledR}$ AFN. The amount of chromium (VI) removed was determined in terms of the following parameters: initial concentration of chromium (VI), type of anion-exchange membrane, concentration of counter-ion and magnetic stirring rate. A 24 full factorial design analysis was performed to screen the parameters affecting the $\mathrm{Cr}$ (VI) removal efficiency. Using the experimental results, a linear mathematical model representing the influence of the different parameters as well as their interactions was obtained. Analysis of the variance (ANOVA), the F-test and the student's test shows that the type of anion-exchange membrane is the most significant parameter affecting the chromium (VI) removal. The statistical analysis of the experimental data assumes it to be a normal distribution.
\end{abstract}

Keywords: Donnan Dialysis; Chromium (VI); Anion-Exchange Membrane; Factorial Design; Optimization

\section{Introduction}

Chromium and its derivatives are widely used in Industrial products such as electroplates, dies, textiles, leather... in which chromium in wastewater is present either in hexavalent form $\mathrm{Cr}$ (VI) or in the trivalent form $\mathrm{Cr}$ (III). Generally, chromium appears to be a nutrient for some plants and animals, including humans; On the other hand, chromium (VI) species have been reported to be toxic to bacteria, plants and animals. Human toxicity includes lung cancer, liver, kidney, gastric damage and epidermal irritation [1]. The maximum contaminant level of chromium in drinking water is $0.05 \mathrm{mg} \cdot \mathrm{L}^{-1}$ [2]. Due to its high toxicity, especially in its hexavalent form, the tolerated concentrations are controlled by strict standards and measures. Therefore, it is necessary to eliminate Cr (VI) from the environment in order to prevent the deleterious impact on ecosystem and public health. There are various treatment technologies available to remove the $\mathrm{Cr}(\mathrm{VI})$ from wastewater such as chemical precipitation [3], ion-exchange [4-9], membrane process as reverse osmosis, ultrafiltration and nanofiltration [10-14], flotation [15], electrocoagulation [16], solvent extraction [17], sedimentation [18], reduction [19], dialysis/electrodialysis [20], adsorption [21-24] and biosorption [25].

The Donnan dialysis is a useful membrane process used to recover valuable ions and remove undesirable ones from some waste effluents [26-34]. The theory and principles behind the Donnan dialysis process are recently reviewed by Luo et al. [35]. A number of fundamental and practiced studies have been conducted including treatment of alkali, alkali earths, transition and rare metals [36-41].

The present study deals with the application and the optimization of the Donnan dialysis in the removal of chromium (VI) from a reconstituted solution. The amount of chromium removed was determined as a function of the following parameters: initial chromium concentration, type of anion-exchange membrane, counter-ion concentration and stirring rate. The experiments have been carread out using a $2^{4}$ full factorial design to study the effect of the main and interaction parameters [42]. This study will allow us to find the best conditions to remove the chromium (VI) by Donnan dialysis. These conditions will be used for a future study on the efficiency of this process for the removal of chromium.

\section{Experimental}

\subsection{Material and Methods}

\subsubsection{Membranes}

For the Donnan dialysis process two AEMs have been 
used: Selemion ${ }^{\circledR}$ AMV and Neosepta ${ }^{\circledR}$ AFN. The AFN membrane was generously provided by Eurodia Industries S.A. and the AMV one was purchased. Details of their chemical structure cannot be known but they do contain tertiary amine functional groups and their properties are listed in Table 1.

Prior to any measurement, it was necessary to condition the samples in order to stabilize their physical-chemical properties and remove any impurities that may come from their manufacturing process. The French standard NF X 45-200 was followed to achieve this treatment [43].

\subsubsection{Reagents}

The stock solutions of chromium (VI) were prepared by dissolving sodium chromate salt $\left(\mathrm{Na}_{2} \mathrm{Cr}_{2} \mathrm{O}_{7}\right)$ in 1.0 liter of distilled water to have an initial concentration of $\mathrm{Cr}$ (VI) $1.0 \mathrm{~g} \cdot \mathrm{L}^{-1}$. Under these conditions, the $\mathrm{pH}$ of the solution is close to 4 and the dominant ion is therefore the $\mathrm{HCrO}_{4}^{-}$. All other reagents used $\left(\mathrm{Na}_{2} \mathrm{Cr}_{2} \mathrm{O}_{7} ; \mathrm{NaOH} ; \mathrm{NaCl}\right.$; 1,5-diphenylcarbazide) were analytical reagent grade.

\subsubsection{Donnan Dialysis}

Figure 1 shows the device used to study the chromium (VI) removal by Donnan Dialysis. It is composed of a thermoregulated water bath $\left(25.0^{\circ} \mathrm{C} \pm 0.1^{\circ} \mathrm{C}\right.$ in this study), containing a cell with feed and receiver compartments separated by an anion-exchange membrane. The solutions are pumped through the cell with a peristaltic pump fitted with a pair of identical heads and a speed variator allowing for variable flow rates. The hydrodynamic conditions on both sides of the membrane can be adjusted by two variable speed stirring rods. The dialysis cell consists in two detachable compartments made with polymethylmetacrylate (plexiglass). It is composed of four parts joined by three stainless steel treaded rods. The centring is assured by bolsters.

The two central compartments, consisting of two tubes are symmetrical. Three threaded holes penetrate each compartment and serve as supports for stuffing boxes. The membrane is sandwiched between these two compartments, making a seal at the same time [44].

Table 1. Properties of the two anion-exchange membranes used in this study.

\begin{tabular}{ccc}
\hline Parameter & Selemion $^{\circledR}$ AMV & Neosepta $^{\circledR}$ AFN \\
\hline Type & Homogeneous & Homogeneous \\
Structure property & PS/butadiene & PS/DVB \\
Fixed ionic group & $-\mathrm{NR}_{3}^{+}$ & $-\mathrm{NR}_{3}^{+}$ \\
$\begin{array}{c}\text { Ion-exchange } \\
\left.\text { capacity (mmol } \cdot \mathrm{g}^{-1}\right)\end{array}$ & 1.85 & 3.15 \\
Water content $(\%)$ & 19.9 & 40.5 \\
Thickness $(\mathrm{mm})$ & 0.11 & 0.12 \\
\hline
\end{tabular}

To supply the receiver compartment an $\mathrm{NaCl}$ or $\mathrm{NaCl}$ solution is used at the concentration of 0.01 Mor $0.1 \mathrm{M}$. The feed compartment is filled with Chromium (VI) solution at the concentration of 100 or $300 \mathrm{mg} \cdot \mathrm{L}^{-1}$.

The samples were analyzed for residual Chromium (VI) concentration by reaction with 1,5-diphenylcarbazide followed by absorbance measurement at $540 \mathrm{~nm}$ using a UV-visible spectrophotometer. This method was validated in a previous study [45].

The removal rate of chromium was calculated by using to Equation (1):

$$
Y_{\mathrm{Cr}}(\%)=\frac{C_{0}-C_{e}}{C_{0}} \times 100
$$

where $C_{0}$ and $C_{e}$ are the initial and equilibrium concentrations $\left(\mathrm{mg} \cdot \mathrm{L}^{-1}\right)$, respectively.

\subsection{Factorial Design}

A Factorial design, with 16 experiments for 4 factors (Table 2), was carried out as a screening approach to find the significant factors affecting the responses. The experiments, presented in Table 3, were executed in a random order. For every experiment performed, a reagent blank was also prepared. All measurements were run in triplicate for the sample solution. The effect of the factor i can be estimated from $b_{i}$ (Equation (2)):

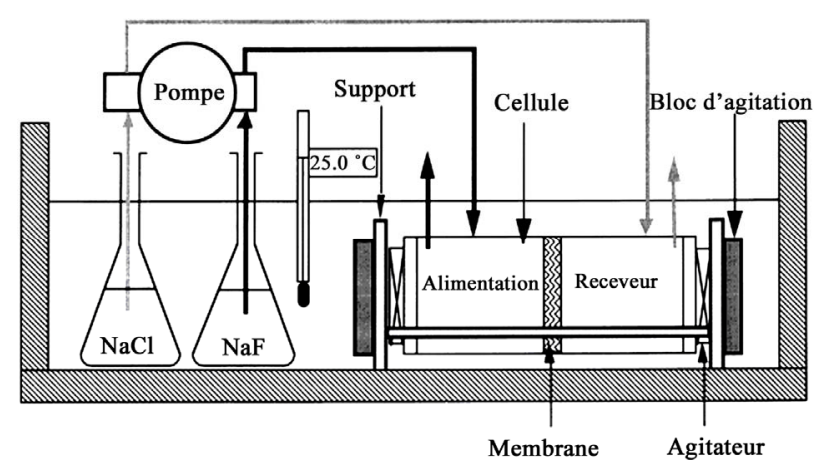

Figure 1. The experimental device of the Donnan dialysis process.

Table 2. Experimental ranges and level of the factors studied in the factorial design.

\begin{tabular}{lccc}
\hline \multicolumn{1}{c}{ Factor } & $\begin{array}{c}\text { Coded } \\
\text { symbol }\end{array}$ & \multicolumn{2}{c}{ Rang and level } \\
\cline { 3 - 4 } & $X_{1}$ & 100 & 300 \\
\hline $\begin{array}{l}\text { Initial concentration of chromium } \\
\left(\mathrm{C}_{1}, \mathrm{mg} \cdot \mathrm{L}^{-1}\right)\end{array}$ & $X_{2}$ & 0.01 & 0.1 \\
$\begin{array}{l}\text { Concentration counterion } \\
\left(\mathrm{C}_{2}, \mathrm{mg} \cdot \mathrm{L}^{-1}\right)\end{array}$ & $X_{3}$ & $\mathrm{AMV}$ & $\mathrm{AFN}$ \\
$\begin{array}{l}\text { Type of AEM } \\
\text { Magnetic stirring }(\omega, \mathrm{rpm})\end{array}$ & $X_{4}$ & 200 & 900 \\
\hline
\end{tabular}


Table 3. Studied parameters in their reduced and normal forms.

\begin{tabular}{cccccccccc}
\hline Experiment & $\mathbf{C}_{\mathbf{1}}\left(\mathbf{m g} \cdot \mathbf{L}^{-\mathbf{1}}\right)$ & $\boldsymbol{X}_{\mathbf{1}}$ & $\mathbf{C}_{\mathbf{2}}\left(\mathbf{m o l} \cdot \mathbf{L}^{-\mathbf{1}}\right)$ & $\boldsymbol{X}_{\mathbf{2}}$ & AEM & $\boldsymbol{X}_{\mathbf{3}}$ & $\mathbf{( \omega , \mathbf { r p m } )}$ & $\boldsymbol{X}_{\mathbf{4}}$ & $\boldsymbol{Y}_{\boldsymbol{C r}}(\mathbf{\%})$ \\
\hline $\mathbf{1}$ & 100 & -1 & 0.01 & -1 & AMV & -1 & 200 & -1 & 4.0 \\
$\mathbf{2}$ & 300 & 1 & 0.01 & -1 & AMV & -1 & 200 & -1 & 1.4 \\
$\mathbf{3}$ & 100 & -1 & 0.1 & 1 & AMV & -1 & 200 & -1 & 9.1 \\
$\mathbf{4}$ & 300 & 1 & 0.1 & 1 & AMV & -1 & 200 & -1 & 3.4 \\
$\mathbf{5}$ & 100 & -1 & 0.01 & -1 & AFN & 1 & 200 & -1 & 12.7 \\
$\mathbf{6}$ & 300 & 1 & 0.01 & -1 & AFN & 1 & 200 & -1 & 12.9 \\
$\mathbf{7}$ & 100 & -1 & 0.1 & 1 & AFN & 1 & 200 & -1 & 22.0 \\
$\mathbf{8}$ & 300 & 1 & 0.1 & 1 & AFN & 1 & 200 & -1 & 16.1 \\
$\mathbf{9}$ & 100 & -1 & 0.01 & -1 & AMV & -1 & 900 & 1 & 3.1 \\
$\mathbf{1 0}$ & 300 & 1 & 0.01 & -1 & AMV & -1 & 900 & 1 & 2.5 \\
$\mathbf{1 1}$ & 100 & -1 & 0.1 & 1 & AMV & -1 & 900 & 1 & 4.5 \\
$\mathbf{1 2}$ & 300 & 1 & 0.1 & 1 & AMV & -1 & 900 & 1 & 2.9 \\
$\mathbf{1 3}$ & 100 & -1 & 0.01 & -1 & AFN & 1 & 900 & 1 & 20.0 \\
$\mathbf{1 4}$ & 300 & 1 & 0.01 & -1 & AFN & 1 & 900 & 1 & 18.9 \\
$\mathbf{1 5}$ & 100 & -1 & 0.1 & 1 & AFN & 1 & 900 & 1 & 23.0 \\
$\mathbf{1 6}$ & 300 & 1 & 0.1 & 1 & AFN & 1 & 900 & 1 & 18.9 \\
\hline
\end{tabular}

$$
b_{i}=\frac{\sum y_{i}^{+}-\sum y_{i}^{-}}{N}
$$

where $\sum y_{i}^{+}$is the sum of the responses for which factor $i$ is on the high level $\left(+X_{i}=+1\right), \sum y_{i}^{-}$is the sum of the responses for which factor $i$ is on low level $\left(-X_{i}=-1\right)$, and $N$ is the number of experiments. The theoretical response at $X_{i}=0$ can be estimated from $b_{0}$ :

$b_{0}=\frac{\sum y_{i}^{+}}{N}$

To increase the response, the factor $i$ must be maintained [46]:

$\checkmark$ at the high level (+) if $b_{i}$ is positive;

$\checkmark$ at the low level (-) if $b_{i}$ is negative.

\section{Results and Discussion}

\subsection{Effect of Counter-Ion}

The type of counter-ion has an important effect on transport of $\mathrm{Cr}(\mathrm{VI})$ through the AEM. Two counter-ions, $\mathrm{Cl}^{-}$ and $\mathrm{OH}^{-}$, were chosen for their difference in their diffusion coefficient values and their chemical behavior. These two counter-ions are commonly used in Donnan dialysis and remain not expensive for industrial applications. The counter-ion was fitted in the receiver compartment, and as the feed compartment a solution of $\mathrm{Cr}$ (VI) at 100 $\mathrm{mg} \cdot \mathrm{L}^{-1}$ has been used. In this part, the two compartments are separated by the AMV membrane and the dialysis operations lasted six hours. Each hour, a sample has been taken from the receiver to measure the concentration of chromium. The obtained results indicate a progressive and continuous increase in the concentration of chromium (VI) in the receiver compartment. It appears that $\mathrm{OH}^{-}$counter-ion gives better chromium (VI) transport through the AMV membrane. However, it should be indicated that color of the feed compartment changes from yellow to yellow-green when using $\mathrm{OH}^{-}$, while it remains unchanged (yellow) where $\mathrm{Cl}^{-}$was used. This is due to the effect of the $\mathrm{pH}$ variation of the feed compartment leading to a change in the nature of the ions present. Indeed, it was found that the $\mathrm{pH}$ becomes very alkaline ( 11) and therefore the dominant ion is $\mathrm{Cr}(\mathrm{OH})_{3}$ which is known to be green. Thus, in spite of $\mathrm{OH}^{-}$counter-ion provides better chromium (VI) removal, the choose to not use it because its presence in feed compartment alters the initial composition of the predominant species in the solution.

\subsection{Empirical Modeling}

\subsubsection{Factorial Design}

In order to obtain the optimum conditions for the removal of chromium (VI) by Donnan dialysis, a full factor design has been used. A factorial design is a multi-factor cross-group design. It can not only test the differences between various levels of each factor, but also test the interaction between the factors. If there is interaction between two or more factors indicating these factors are interdependent, which means that when the level of a factor changes, the effect of one or several factors changes accordingly. In opposition, if there is no interaction indicating the independence of various factors, changes in the level of a factor do not affect the effects of other factors. 
The factorial design of the type $n^{k}$ has been used, where $n=$ number of levels and $k=$ number of factors under verification (here $n=2$ and $k=4$ ). Thus, the total number of trial experiments needed for an investigation is $2^{4}$. If $Y_{C r}$ (removal efficiency of chromium (VI)) is the response variable, then the regression equation with four parameters and their interaction Equation (3) is given by Akhnazarova and Katarov [47] (see Tables 2 and 3):

$$
\begin{aligned}
Y= & b_{0}+b_{1} X_{1}+b_{2} X_{2}+b_{3} X_{3}+b_{4} X_{4} \\
& +b_{12} X_{1} X_{2}+b_{13} X_{1} X_{3}+b_{14} X_{1} X_{4} \\
& +b_{23} X_{2} X_{3}+b_{24} X_{2} X_{4}+b_{34} X_{3} X_{4}
\end{aligned}
$$

where $b_{0}, b_{1}, b_{2}, b_{3}$ and $b_{4}$ are the linear coefficients, $b_{12}$, $b_{13}, b_{14}, b_{23}, b_{24}$ and $b_{34}$ are the second-order interaction terms. $X_{1}, X_{2}, X_{3}$ and $X_{4}$ are the dimensionless coded factors of the following parameters studied initial concentration of chromium (VI), concentration of counter-ion, type of the anion-exchange membrane and magnetic stirring, respectively. In Table 2 , the low and high levels are mentioned for the studied parameters.

According to the factorial design for chromium (VI) removal, sixteen $\left(2^{4}\right)$ experiments have been taken out following the matrix in Table 3.

The effect, regression coefficients, standard errors, $\mathrm{T}$ values (standardized effects) are gathered in Table 4.

By substituting the coefficients in Equation (3) with their values from Table 4 it can derive a model equation relating the level of parameters to the chromium removal

\begin{tabular}{|c|c|c|c|c|c|}
\hline Term & Effect & Coefficient & $\begin{array}{l}\text { Standard } \\
\text { error }\end{array}$ & $\mathbf{T}$ & $\mathbf{P}$ \\
\hline Constant & & 10.963 & 0.2823 & 38.8 & 0.000 \\
\hline Cr (VI) & -2.675 & -1.337 & 0.2823 & -4.74 & 0.005 \\
\hline $\mathrm{Cl}^{-}$ & 3.050 & 1.525 & 0.2823 & 5.40 & 0.003 \\
\hline AEM & 14.20 & 7.100 & 0.2823 & 25.15 & 0.000 \\
\hline$\omega$ & 1.525 & 0.762 & 0.2823 & 2.70 & 0.043 \\
\hline $\mathrm{Cr}(\mathrm{VI})-\mathrm{Cl}^{-}$ & -1.650 & -0.825 & 0.2823 & -2.92 & 0.033 \\
\hline Cr(VI)-AEM & -0.050 & -0.025 & 0.2823 & -0.09 & 0.933 \\
\hline $\operatorname{Cr}(\mathrm{VI})-\omega$ & 0.825 & 0.412 & 0.2823 & 1.46 & 0.204 \\
\hline $\mathrm{Cl}^{-}$-AEM & 0.825 & 0.413 & 0.2823 & 1.46 & 0.204 \\
\hline $\mathrm{Cl}^{-}-\omega$ & -1.850 & -0.925 & 0.2823 & -3.28 & 0.022 \\
\hline AEM- $\omega$ & 2.750 & 1.375 & 0.2823 & 4.87 & 0.005 \\
\hline
\end{tabular}
efficiency Equation (4):

Table 4. Statistical parameters for a $2^{4}$ design.

$$
\begin{aligned}
Y_{c r}= & 10.963-1.337 X_{1}+1.525 X_{2}+7.100 X_{3} \\
& +0.762 X_{4}-0.825 X_{1} X_{2}-0.025 X_{1} X_{3} \\
& +0.412 X_{1} X_{4}+0.413 X_{2} X_{3}-0.925 X_{2} X_{4} \\
& +1.3765 X_{3} X_{4}
\end{aligned}
$$

\subsubsection{The Student's T-Test}

The Student's t-test was carried out to determine whether the calculated main and interaction effects were significantly different from zero. Absolute values of the main factors and the interaction of factors are illustrated in Pareto chart (Figure 2) in the horizontal columns. With a $95 \%$ confidence level and sixteen degrees of freedom, the $t$ value was equal to 2.57 . To indicate the minimum level, a vertical line is drawn in the Pareto chart. The bars for $\mathrm{BC}, \mathrm{AD}$ and $\mathrm{AC}$ remained inside the reference line in the Pareto chart, showing that these terms contributed the least to the prediction of $\mathrm{Cr}$ (VI) removal efficiency.

\subsubsection{Analysis of Variance (ANOVA)}

In order to determine the significant main and interaction effects of factors influencing the removal efficiency of $\mathrm{Cr}$ (VI), an analysis of variance (ANOVA) was performed. The sum of squares (SS) and mean square (MS) of each factor, P-value and the F-ratio, defined as the ratio of the respective mean square effect and the mean square error, are shown in Table 5. Since for a 95\% confidence level, 1 degree of freedom and 16 factorial tests $\mathrm{F}_{0.05,1}$, 1.16 is equal to 4.49 , all the effects with F-values higher than 4.49 are significant.

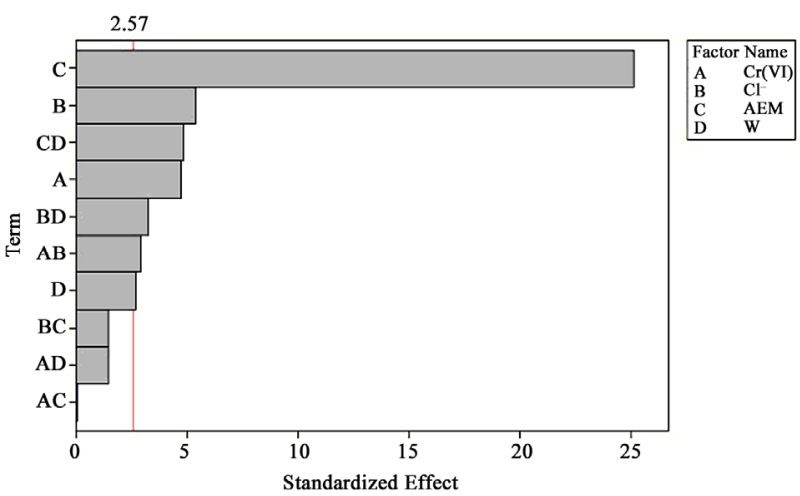

Figure 2. Pareto chart for standardized effects.

Table 5. Analysis of variance.

\begin{tabular}{cccccc}
\hline $\begin{array}{c}\text { Source } \\
\text { model }\end{array}$ & Df & SS & MS & F-value & P-value \\
\hline Main effect & 4 & 881.7 & 220.4 & 172.8 & 0.000 \\
Interaction & 6 & 60.3 & 10.0 & 7.9 & 0.019 \\
Residual & 5 & 6.4 & 1.3 & & \\
Total & 15 & 948.4 & & & \\
\hline
\end{tabular}


P-value is the probability value used to determine the statistically significant effects in the model. The importance of the data can be judged by its P-value, where values closer to zero denote greater significance. According to the obtained F-value and P-value, it seems that the effect of initial concentration of chromium $\mathrm{Cr}$ (VI) (A), concentration of counter-ion $\mathrm{Cl}^{-}(\mathrm{B})$, type of anion-exchange membrane AEM (C), magnetic stirring $\omega$ (D), and the interaction effect of initial concentration of chromium $\mathrm{Cr}(\mathrm{VI})$ and concentration of counter-ion $\mathrm{Cl}^{-}(\mathrm{A} \times$ $\mathrm{B})$, concentration of counter-ion $\mathrm{Cl}^{-}$and magnetic stirring $\omega(\mathrm{B} \times \mathrm{D})$, type of anion-exchange membrane and magnetic stirring $\omega(\mathrm{C} \times \mathrm{D})$ are statistically significant.

\subsubsection{Main and Interaction Effects}

Analyzing the graphs of Figure 3 which represents the main effects and analyzing the coefficient of Equation (3), it can be inferred that the type of anion-exchange membrane has the most important variable since its coefficient was the largest (i.e. 7.10). The positive sign of the coefficient for the type of AEM means that Cr (VI) removal was improved with AFN anion-exchange membrane. This is due to the high ion-exchange capacity of AFN compared to that of AMV and also due to its water content. The counter-ion concentration and the chromium (VI) concentration have moderately significant effects on the removal of chromium by Donnan dialysis.

The magnetic stirring has little influence on the chromium (VI) removal. This can be explained by the fact that the diffusion boundary layers thickness decreases significantly from 0 to $200 \mathrm{rpm}$ but the thickness remains almost constant from 200 to $900 \mathrm{rpm}$ [48]. The most significant interaction is between the type of anion-exchange membrane and magnetic stirring. The AFN membrane gives an important concentration of chromium (VI) in receiver compartment. This is due to the difference on the surface state of both used AEM. Indeed, the AFN membrane is reinforced with a PVC frame, which gives significant roughness at the surface. This roughness creates turbulence which increases sharply with stirring.

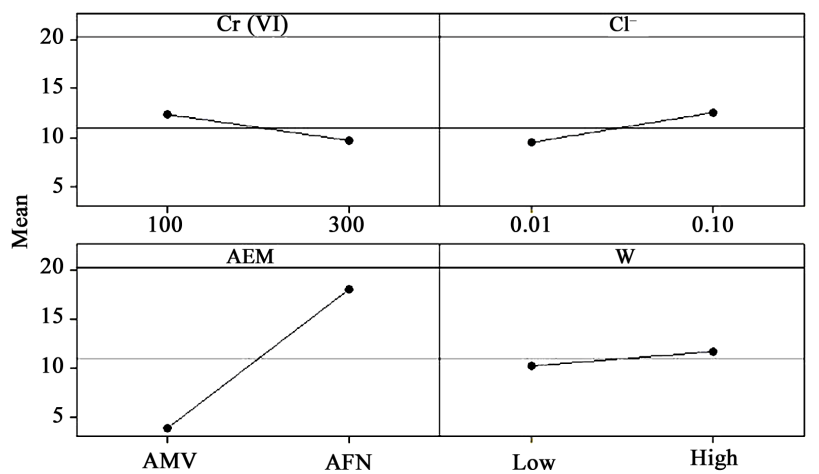

Figure 3. Main effects plot for $\mathrm{Cr}$ (VI) removal.
Thus, the diffusion boundary layers are reduced and the passage of $\mathrm{HCrO}_{4}^{-}$ions is easier. The interaction effects plots are shown in Figure 4. The non-parallel lines in this figure are indications of interaction between the two factors. The graphs of Figure $\mathbf{4}$ and coefficients of Equation (3) show negative interaction between initial concentration of chromium (VI) and counter-ion concentration $\mathrm{Cl}^{-}(\mathrm{A} \times \mathrm{B})$, and counter-ion concentration $\mathrm{Cl}^{-}$and magnetic stirring $\omega(\mathrm{B} \times \mathrm{D})$.

A positive interactive effect was also observed between initial concentration of chromium $\mathrm{Cr}$ (VI) and magnetic stirring $(\mathrm{A} \times \mathrm{D})$, counter-ion concentration $\mathrm{Cl}^{-}$and type of anion-exchange membrane AEM $(B \times C)$ and type of anion-exchange membrane AEM and magnetic stirring $(\mathrm{B} \times \mathrm{D})$.

The interaction $(\mathrm{A} \times \mathrm{B})$ shows that the initial concentration of chromium $100 \mathrm{mg} \cdot \mathrm{L}^{-1}$ and the counter-ion concentration $\left(0.1 \mathrm{~mol} \cdot \mathrm{L}^{-1}\right)$ improve the removal of chromium. The interaction $(\mathrm{A} \times \mathrm{C})$ confirms that the effect of AEM is the most influent and indicates that AFN is the best membrane for the chromium (VI) removal. The interaction $(A \times D)$ indicates that the increasing of the magnetic stirring rate had an effect only for high concentration of $\mathrm{Cr}$ (VI) and this is due to the decrease of the diffusion boundary layers thickness. The interaction $(\mathrm{B} \times \mathrm{C})$ indicates that the combination AFN and the high concentration of counter-ion provide a better removal.

The interaction $(\mathrm{B} \times \mathrm{D})$ confirms that the increase of magnetic stirring speed reduces the diffusion boundary layers thickness which facilitates the passage of $\mathrm{HCrO}_{4}^{-}$. The interaction $(\mathrm{C} \times \mathrm{D})$ confirms the difference of surface state of both used membrane.

\subsubsection{Normal Probability Plot of Residuals}

The normality of the data can be checked by plotting a normal probability plot of the residuals. If the data points on the plotfall fairly close to the straight line, then the data are normally distributed [49]. To determine whether or not the data set is normally distributed, the normal probability plot of residual values is shown in Figure 5. The data set has normal distribution if the points fall

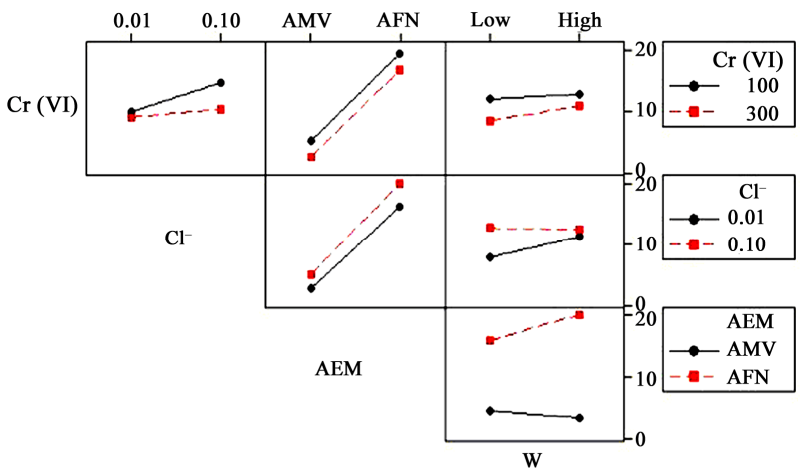

Figure 4. Interaction effects plot for $\mathrm{Cr}$ (VI) removal. 


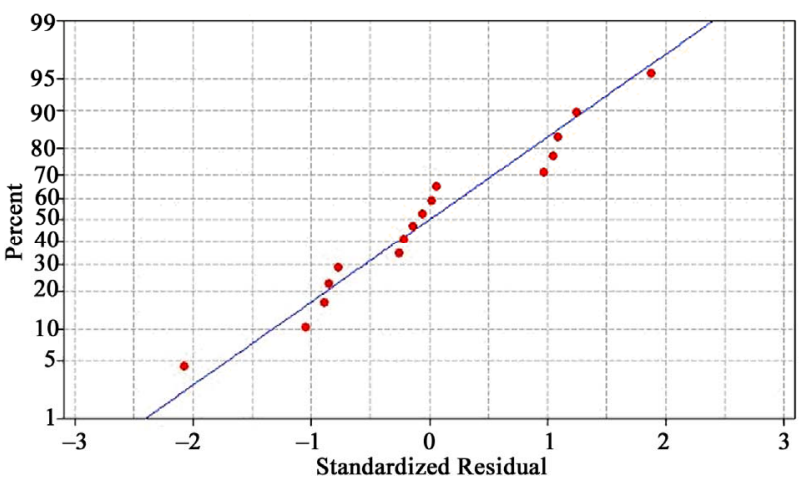

Figure 5. Normal probability plot of residuals for Cr (VI) removal efficiency.

close enough to the straight line. It is evident from Figure 5 that experimental points follow a straight line suggesting the normal distribution of the data.

\section{Conclusions}

This study shows that the type of anion-exchange membrane has the most significant impact on the removal of the chromium (VI), this is due to the difference of the surface state of both AEMs used. On the other hand, the analysis of variance (ANOVA), t-test and F-test shows that the interactions of $(\mathrm{A} \times \mathrm{B}),(\mathrm{B} \times \mathrm{D})$ and $(\mathrm{C} \times \mathrm{D})$ are the most statistically significant. Finally, the statistical analysis of the experimental data assumes that the data have a normal distribution.

After the optimal conditions for carrying out a Donnan Dialysis operation are researched, a complete study on the efficiency of this process is being conducted for the removal of chromium (VI) and the possibility of its coupling with another process: the adsorption on activated alumina.

\section{REFERENCES}

[1] D. E. Kimbrough, Y. Cohen, A. M. Winer, L. Creelman and C. A. Mabuni, "Critical Assessment of Chromium in the Environment," Critical Reviews in Environmental Science and Technology, Vol. 29, No. 1, 1999, pp. 1-46. doi:10.1080/10643389991259164

[2] V. K. Gupta, M. Gupta and S. Sharma, "Process Development for the Removal of Lead and Chromium from Aqueous Solutions using Red Mud-An Aluminium Industry Waste," Water Research, Vol. 35, No. 5, 2001, pp. 11251134. doi:10.1016/S0043-1354(00)00389-4

[3] J. W. Paterson, "Wastewater Treatment Technology," Ann Arbour Science, Michigan, 1975.

[4] G. Tiravanti, D. Petruzzelli and R. Passino, "Pretreatment of Tannery Wastewaters by an Ion Exchange Process for Cr (III) Removal and Recovery," Water Science Technology, Vol. 36, No. 2-3, 1997, pp. 197-207. doi:10.1016/S0273-1223(97)00388-0

[5] S. Rengaraj, K. H. Yeon and S. H. Moon, "Removal of
Chromium from Water and Wastewater by Ion Exchange Resins," Journal of Hazardous Materials, Vol. 87, No. 1-3, 2001, pp. 273-287. doi:10.1016/S0304-3894(01)00291-6

[6] S. Rengaraj, K. H. Yeon, S. Y. Kang, J. U. Lee, K. W. Kim and S. H. Moon, "Studies on Adsorptive Removal of $\mathrm{Co}(\mathrm{II}), \mathrm{Cr}(\mathrm{III})$ and $\mathrm{Ni}(\mathrm{II})$ by IRN77 Cation-Exchange Resin," Journal of Hazardous Materials, Vol. 92, No. 2, 2002, pp. 185-198. doi:10.1016/S0304-3894(02)00018-3

[7] S. Rengaraj, C. K. Joo, Y. Kim and J. Yi, "Kinetics of Removal of Chromium from Water and Electronic Process Wastewater by Ion Exchange Resins: $1200 \mathrm{H}, 1500 \mathrm{H}$ and IRN97H," Journal of Hazardous Materials, Vol. 102, No. 2, 2003, pp. 257-275. doi:10.1016/S0304-3894(03)00209-7

[8] D. Petruzzelli, R. Passino and G. Tiravanti, "Ion Exchange Process for Chromium Removal and Recovery from Tannery Wastes," Industrial \& Engineering Chemistry Research, Vol. 34, No. 8, 1995, pp. 2612-2617. doi:10.1021/ie00047a009

[9] F. Gode and E. Pehlivan, "Sorption of Cr (III) onto Chelating b-DAEG-sporopollenin and CEP-Sporopollenin Resins," Bioresource Technology, Vol. 98, No. 4, 2007, pp. 904-911. doi:10.1016/j.biortech.2006.02.043

[10] C. A. Kozlowski and W. Walkowiak, "Removal of Chromium (VI) from Aqueous Solutions by Polymer Inclusion Membranes," Water Research, Vol. 36, No. 19, 2002, pp. 4870-4876. doi:10.1016/S0043-1354(02)00216-6

[11] H. Shaalan, M. Sorour and S. Tewfik, "Simulation and Optimization of a Membrane System for Chromium Recovery from Tanning Wastes," Desalination, Vol. 141, No. 3, 2001, pp. 315-324. doi:10.1016/S0011-9164(01)85008-6

[12] G. Ghosh and P. K. Bhattacharya, "Hexavalent Chromium Ion Removal through Micellar Enhanced Ultrafiltration," Chemical Engineering Journal, Vol. 119, No. 1, 2006, pp. 45-53. doi:10.1016/j.cej.2006.02.014

[13] H. Ozaki, K. Sharma and W. Saktaywin, "Performance of an Ultra-Low Pressure Reverse Osmosis Membrane (ULPROM) for Separating Heavy Metal: Effects of Interference Parameters," Desalination, Vol. 144, No. 1-3, 2002, pp. 287-294. doi:10.1016/S0011-9164(02)00329-6

[14] M. Muthukrishnan and B. K. Guha, "Effect of pH on Rejection of Hexavalent Chromium by Nanofiltration," Desalination, Vol. 219, No. 1-3, 2008, pp. 171-178.

[15] K. A. Matis and P. Mavros, "Recovery of Metals by Ion Flotation from Dilute Aqueous Solutions," Separation and Purification Methods, Vol. 20, No. 1, 1991, pp. 1-48. doi:10.1080/03602549108021407

[16] J. R. Parga, D. L. Cocke, V. Valverde, J. A. G. Gomes, M. Kesmez, H. Moreno, M. Weir and D. Mencer, "Characterization of Electrocoagulation for Removal of Chromium and Arsenic," Chemical Engineering \& Technology, Vol. 28, No. 5, 2005, pp. 605-612. doi:10.1002/ceat.200407035

[17] E. Salazar, M. I. Ortiz and A. M. Urtiaga, "Equilibrium and Kinetics of Cr (VI) Extraction with Aliquat 336," Industrial \& Engineering Chemistry Research, Vol. 31, No. 6, 1992, pp. 1516-1522.

[18] Z. Song, C. J. Williams and R. G. J. Edyvean, "Sedimen- 
tation of Tannery Wastewater," Water Research, Vol. 34, No. 7, 2000, pp. 2171-2176. doi:10.1016/S0043-1354(99)00358-9

[19] J. M. N. Chen and O. J. N. Hao, "Microbial Chromium (VI) Reduction," Critical Reviews in Environmental Science and Technology, Vol. 28, No. 3, 1998, pp. 219-251. doi:10.1080/10643389891254214

[20] T. Mohammadi, A. Moheb, M. Sadrzadeh and A. Razmi, "Modeling of Metal Ion Removal from Wastewater by Electrodialysis," Separation and Purification Technology, Vol. 41, No. 1, 2005, pp. 73-82. doi:10.1016/j.seppur.2004.04.007

[21] V. K. Gupta, I. Ali and Somasundaran, "Adsorbents for Water Treatment: Development of Low Cost Alternatives to Carbon for the Updated," Encyclopedia of Surface and Colloid science, Marcel Dekker, New York, 2003.

[22] V. K. Gupta, K. T. Park, S. Sharma and D. Mohan, "Removal of Chromium (VI) from Electroplating Industry Wastewater Using Bagasse Flyash-A Sugar Industry Waste Material," Environmentalist, Vol. 19, No. 2, 1999, pp. 129-136. doi:10.1023/A:1006693017711

[23] V. K. Gupta, S. K. Srivastava and D. Mohan, "Design Parameters for Fixed Bed Reactors of Activated Carbon Developed from Fertilizer Waste for The Removal of Some Heavy Metal Ions," Waste Management, Vol. 17, No. 8, 1997, pp. 517-522. doi:10.1016/S0956-053X(97)10062-9

[24] S. Babel and T. A. Kurniawan, "Low Cost Adsorbents for Heavy Metals Uptake from Contaminated Water: A Review," Journal of Hazardous Materials, Vol. B97, No. 1-3, 2003, pp. 219-243. doi:10.1016/S0304-3894(02)00263-7

[25] C. Quintelas, B. Fonseca, B. Silva, H. Figueiredo and T. Tavares, "Treatment of Chromium (VI) Solutions in a Pilot-Scale Bioreactor through a Biofilm of ArthrobacterViscosus Supported on GAC," Bioresource Technology, Vol. 100, No. 1, 2009, pp. 220-226. doi:10.1016/j.biortech.2008.05.010

[26] G. Wisniewska and T. Winnicki, “Acidic Wastewater Treatment by Donnan Dialysis Involving Tubular Anion Exchange Membranes," Desalination, Vol. 68, No. 2-3, 1998, pp. 121-130. doi:10.1016/0011-9164(88)80049-3

[27] K. Pyrzynska, "Atomic Absorption Spectrophotometric Determination of Gold with Preconcentrationby Donnan Dialysis," Talanta, Vol. 41, No. 3, 1994, pp. 381-386. doi:10.1016/0039-9140(94)80142-8

[28] J. E. DiNunzio and M. Jubara, "Donnan Dialysis Preconcentration for Ion Chromatography," Analytical Chemistry, Vol. 55, No. 7, 1983, pp. 1013-1016. doi:10.1021/ac00258a008

[29] A. Dieye, C. Larchet, B. Auclair and C. Mar-Diop, "Elimination des Fluorures par la Dialyse Ionique Croisée," European Polymer Journal, Vol. 34, No. 1, 1998, pp. 67-75. doi:10.1016/S0014-3057(97)00079-7

[30] M. Hichour, F. Persin, J. Molenat, J. Sandeaux and C. Gavach, "Fluoride Removal from Diluted Solutions by Donnan Dialysis with Anion Exchange Membranes," Desalination, Vol. 122, No. 1, 1999, pp. 53-62.

[31] M. Hichour, F. Persin, J. Sandeaux and C. Gavach, "Flu- oride Removal from Waters by Donnan Dialysis," Separation and Purification Technology, Vol. 18, No. 1, 2000, pp. 1-11. doi:10.1016/S1383-5866(99)00042-8

[32] J. Seneviratne, S. D. Holmstrom and J. A. Cox, "Donnan Dialysis Preconcentration Coupled with Ion Chromatography and Electrocatalytic Oxidation for the Determination of Cyanide," Talanta, Vol. 52, No. 6, 2000, pp. 1025-1031. doi:10.1016/S0039-9140(00)00478-1

[33] W. S. H. Ho and K. K. Sirkdar, "Dialysis in Membrane," Handbook, Part IV, Van Nostrand Reinhold, New York, 1992.

[34] Y. Cengeloglu, A. Tor, E. Kir and M. Ersoz, "Transport of Hexavalent Chromium through Anion Exchange Membranes," Desalination, Vol. 154, No. 3, 2003, pp. 239246. doi:10.1016/S0011-9164(03)80039-5

[35] J. Luo, C. Wu, T. Xu and Y. Wu, "Diffusion DialysisConcept, Principle and Applications," Journal of Membrane Science, Vol. 366, No. 1-2, 2011, pp. 1-16. doi:10.1016/j.memsci.2010.10.028

[36] S. T. Hwang and K. Kammermeyer, "Electromembrane Processes Membranes in Separation, Techniques of Chemistry," Wiley/Interscience, New York, 1975.

[37] L. Picincu and D. Pletcher, "The Transport of $\mathrm{Cu}$ (II) through a Sulfonated Styrene/Divinylbenzene Copolymer Membrane," Journal of Membrane Science, Vol. 147, No. 2, 1998, pp. 257-263. doi:10.1016/S0376-7388(98)00128-8

[38] V. Kislik and A. Eyal, "Aqueous Hybrid Liquid Membrane Process for Metal Separation: Part II. Selectivity of Metals Separation from Wet-Process Phosphoric Acid," Journal of Membrane Science, Vol. 169 No. 14, 2000, pp. 133-146. doi:10.1016/S0376-7388(99)00332-4

[39] D. E. Akretche and H. Kerdjoudj, "Donnan Dialysis of Copper, Gold and Silver Cyanides with Various Anion Exchange Membranes," Talanta, Vol. 51, No. 2, 2000, pp. 281-289. doi:10.1016/S0039-9140(99)00261-1

[40] K. Pyrzynska, "Membrane Method for Preconcentrating and Separating Gold Complexes from Aqueous Solutions Containing Other Platinum Group Metals," Analytica Chimica Acta, Vol. 255, No. 1, 1991, pp. 169-175. doi:10.1016/0003-2670(91)85103-Y

[41] Y. Yang and P.N. Pintauro, "Multicomponent SpaceCharge Transport Model for Ion-Exchange Membranes," AIChE Journal, Vol. 46, No. 6, 2000, pp. 1177-1190. doi:10.1002/aic.690460610

[42] J. E. DiNunzio, R. L. Wilson and F. P. Gatchell, "Preconcentration of some Transition and Rare-Earth Elements by Donnan Dialysis," Talanta, Vol. 30, No. 1, 1983, pp. 57-59. doi:10.1016/0039-9140(83)80012-5

[43] French Standard NF X 45-200, "Membranes Polymers Échangeuse d'Ions,” AFNOR, 1995.

[44] L. Dammak, V. Toureuil, C. Larchet and B. Auclair, "Experimental Determination of the Water Flow through Charged Membranes in Bi-Ionic Systems," New Journal of Chemistry, Vol. 21, No. 12, 1997, pp. 1291-1296.

[45] I. Marzouk, C. Hannachi, L. Dammak and B. Hamrouni, "Removal of Chromium by Adsorption onto Activated Alumina," Desalination and Water Treatment, Vol. 26, No. 1-3, 2011, pp. 279-286. doi:10.5004/dwt.2011.1833 
[46] G. A. Lewis, D. Mathieu and R. Phan-Tan-Luu, "Pharmaceutical Experimental Design," Marcel Dekker, New York, 1998. doi:10.1201/9780203508688

[47] S. Akhnazarova and V. Katarov, "Experiment Optimisationin Chemistry and Chemical Engineering," MIR Publishers, Moscow, 1982.

[48] L. Dammak, C. Larchet and B. Auclair, "Theoretical
Study of the Bi-Ionic Potential and Confrontation with Experimental Results," Journal of Membrane Science, Vol. 155, No. 2, 1999, pp. 193-207. doi:10.1016/S0376-7388(98)00307-X

[49] J. Antony, "Design of Experiments for Engineers and Scientists," Butterworth-Heinemann, New York, 2003.

\section{Symbols}

\begin{tabular}{|c|c|c|}
\hline $\mathrm{b}_{0}, \mathrm{~b}_{1}, \mathrm{~b}_{2}, \mathrm{~b}_{3}, \mathrm{~b}_{4}$ & - & Linear coefficients \\
\hline$b_{12}, b_{13}, b_{14}, b_{23}, b_{24}, b_{34}$ & - & Second-order interaction terms \\
\hline $\mathrm{C}_{0}$ & - & Initial concentration of chromium $(\mathrm{VI})\left(\mathrm{mg} \cdot \mathrm{L}^{-1}\right)$ \\
\hline $\mathrm{C}_{\mathrm{e}}$ & - & $\begin{array}{l}\text { Equilibrium concentration of chromium (VI) } \\
\left(\mathrm{mg} \cdot \mathrm{L}^{-1}\right)\end{array}$ \\
\hline AEM & - & Anion-exchange membrane \\
\hline $\mathrm{X}_{1}, \mathrm{X}_{2}, \mathrm{X}_{3}, \mathrm{X}_{4}$ & - & Dimensionless coded factors of parameters \\
\hline $\mathrm{Y}_{\mathrm{Cr}}$ & - & Chromium (VI) removal rate \\
\hline
\end{tabular}

